\title{
A Financial Viability and Relative Profitability of Mango Orcharding in Lucknow District of Uttar Pradesh
}

\author{
Shyam Prakash Singh ${ }^{1}$ and A.K. Nandi ${ }^{2}$
}

${ }^{1}$ Technology and Business Development Division, CSIR-Central Institute of Medicinal and Aromatic Plants, Lucknow-226015, Uttar Pradesh, India

${ }^{2}$ Department of Agricultural Economics, Faculty of Agriculture, BCKV, Mohanpur, Nadia-741252, West Bengal, India

*Corresponding author: shyamsingh7296@gmail.com (ORCID ID: 0000-0003-2376-9982)

Received: 11-09-2019

Revised: 14-01-2020

Accepted: 27-02-2020

\begin{abstract}
The existence of the wide range of natural endowment is very much favorable for growing a large array of horticultural crops throughout the country. The country observed a sharper increase in the area of horticultural crops compared to food grains. In the fruit industry, mango stands top in position. Due to perennial nature, the cost and return behavior has been estimated @ 10 percent opportunity cost of capital as like investment appraisal for the interest of development of mango entrepreneurs. The per hectare net present value (NPV), for the entire life period (55 years) of the mango orchard has been found to be ₹ 600237.34. Benefit-cost ratio is 1.76. The adjusted IRR is also worked out as 19.80 percent, which is sufficiently higher than the opportunity cost of the capital or the rate of interest charged by the financial institutions. The payback period was about 8.2 years. Thus, the evidence reveals that investments in mango orchard are highly profitable, economically feasible and financially viable. To overcome the question of risk and uncertainty in investment over a longer period the usual technique is how sensitive the investment if the cost or return increase/decrease due to economic or other change in the market. Some competing crop performed better in term of benefit-cost ratio, but in terms of average annual net return of ₹ $36030.60 \mathrm{ha}^{-1}$ which was evidently higher than that of alternative crops. The mango cultivation is low input intensive as compared to food grain that means fewer requirements of resources for its production. So, we can say mango production is more profitable venture for resource-poor farmers.
\end{abstract}

\section{Highlights \\ ( Investments in mango orchard are highly profitable and economically feasible. \\ ( $)$ Annual net return of mango orcharding is evidently higher than that of alternative crops. \\ ( Mango orcharding is profitable venture for resource-poor farmers.}

Keywords: Investment appraisal, interest, risk and uncertainty, feasibility, profitability

During the late 60's, the major thrust in agriculture was confined to crop centered seed oriented subsistence agriculture. From 2000 onwards, the traditional agriculture gradually transformed into capital-intensive business oriented agriculture, where the farming community is searching for new avenues to move out from traditional crop husbandry. At present, rural agrarian society has undergone significant phages of socio-economic transformation through the implementation of new liberalized economic policy. Therefore, agrarian base preferred non-farm employment and in some cases shifting of seasonal crop cultivation to high value assured fruit crops. Due to the existence of the wide range of natural endowment, it is very much favorable for growing a large array of horticultural crops throughout the country.

India has witnessed voluminous increase in horticulture production over the last few years.

\footnotetext{
How to cite this article: Singh, S.P. and Nandi, A.K. (2020). A financia viability and relative profitability of mango orcharding in Lucknow district of Uttar Pradesh. Economic Affairs, 65(1): 77-83.
} 
Significant progress has been made in area expansion resulting in higher production. Over the last decade, the area under horticulture grew by about 3\% per annum and annual production increased by $5.4 \%$. During 2018-19, the production of horticulture crops was about 314.87 million tonnes which is 1.01 per cent higher than horticulture production in 2017-18. The area under horticulture crop also rose to 25.60 million hectare from 25.43 million hectare.

Under the horticulture crops, production of fruits is estimated to be around 97.38 million tonnes in 2018-19 compared to 97.36 million tonnes in the 2017-18. In the fruit industry, mango stands top in position. It covered about $34.92 \%$ of the total fruit crops area which holds the second rank in total fruits production of $21.20 \%$; next to banana (DAC\&FW, 2017). Mango is also one of the most consumed fresh fruits in the world and continues to dominate the Indian fruit basket. It comes first among the top-rated delicious fruits and farmers are used to get considerable income which plays a vital role in poverty reduction by providing additional employment opportunity near about 2 million people annually (MOA, 2004-2014). Apart from food security and income to the farmers, the values of foreign exchanges are also remarkable. Mangos occupies the premier position in exports with 46510.27 MT valued at ₹ 40649.55 lakhs (DGCIS, 2018). Keeping these facts in above, it is planned to access the financial viability and relative profitability of mango orcharding in Lucknow district of Uttar Pradesh.

\section{MATERIALS AND METHODS}

The study was conducted during 2016-17 in Lucknow districts of Uttar Pradesh. The third stage of sampling, two blocks were selected and then ten villages from each block were selected using the information received from the individual farm of mango growers. Thus, the sample consisted of 200 farmers of mango. The primary data were collected through personal interview using a pre-tested questionnaire. To study the Financial Viability, Sensitivity and Relative Profitability of mango orchard, project appraisal technique and simple cost and return accounting method were followed. The prices of input and output used in the analysis were the average for the crop harvesting period 2016-17.

\section{Financial Viability Analysis}

In order to determine the financial feasibility of mango orchard, both undiscounted and discounted method of project appraisal techniques have been used. The Benefit-Cost Ratio, Net Present Value and Internal Rate of Return are calculated at $10 \%$ discount rate.

\section{Undiscounted Cash Flow Method}

Undiscounted method is a naive method in which they are not weighed by discount rates. Under this method, Simple Payback Method is used. It is represent the length of time required to recover for the stream of cash proceeds produced by the initial investment to be equal to original cash outlay i.e., the time required for project to pay for itself. In the present study payback period of mango after fruit bearing was calculated. Under the consideration, shorter the payback period, better it will be, and then the investment in a project financially feasible. Symbolically:

$$
\sum_{t=0}^{t} C_{t}=\sum_{t=0}^{t} R_{t}
$$

Where,

$$
\begin{aligned}
& C_{t}=\text { Cost in period ' } t \text { ' } \\
& R_{t}=\text { Return in period ' } t \text { ' }
\end{aligned}
$$

\section{(A) Discounted Cash Flow Method}

On the contrary to the undiscounted method, discounted methods are based on discount rate in which weights are given to the particular discount rate. The various methods under the discounted category are fallows:

\section{(i) Net Present Value or Worth (NPV/W)}

The Net Present Value of an investment is the discounted value of the net cash inflows (all cash inflows and cash outflows) to the project. In the present study a discount factor of 10 per cent was used to discount the net cash inflows representing the opportunity cost of capital. Mathematically, the net present value is estimated as follows:

$$
N P V=\sum_{t=1}^{t=n} \frac{B^{t}-C^{t}}{(1+i)^{t}}
$$


Where,

$N P V=$ Net present value in period ' $t$ '

$B^{t}=$ Benefit from mango orchard in each year

$C^{t}=$ Cost of cultivation in each year

$i=$ Interest rate (discount rate)

$t=1,2,3 \ldots, n$, the entire life of plantation across

the study regions

$n=$ Number of years.

If the calculated NPV is positive it implies the investment is viable, and where the NPV is equal to zero implies that the investment breaks even. The rule with NPV is to accept all mutually exclusive investments with a zero or greater NPV (Gittinger, 1982).

\section{(ii) Internal Rate of Return (IRR)}

Internal Rate of Return is the discount rate at which the present values of the net cash flows are just equal to zero and $\mathrm{B}: \mathrm{C}$ ratio equal to one, $(\mathrm{NPV} / \mathrm{W}=0$ and $\mathrm{B}-\mathrm{C}$ ratio $=1)$. It is most advanced technique to calculate the feasibility or desirability of the investment or project. The internal rate of returns is computed as:

$$
I R R=\sum_{t=1}^{t=n} \frac{B_{t}-C_{t}}{(1+i)^{t}}=0
$$

Where,

$$
\begin{aligned}
& B_{t}=\text { Total benefit }(₹ / \text { ha }) \text { in time } t \\
& \left.C_{t}=\text { Total cost }(₹ / \text { ha })\right) \text { in time } t \\
& r=\text { Rate of interest (discount rate) } \\
& t=\text { Number of years }(1,2,3, \ldots \ldots \ldots \ldots, 55) .
\end{aligned}
$$

The decision rule is to accept all independent projects having an Internal Rate of Return equal to or greater than the cost or opportunity cost of capital (Gittinger, 1982). Specifically, if the IRR is greater than the cost of capital it implies that the investment is viable, when it is equal to the cost of capital the project will break even and when smaller than the cost of capital the investment is not viable.

\section{(iii) Benefit- Cost Ratio (B-CR)}

The benefit-cost ratio of an investment is the ratio of the discounted value of all cash inflows to the discounted value of all cash outflows during the life of the project. The B-CR measures the social equity and economic efficiency of resource utilization. It can be estimated as follows:

$$
B-C R=\sum_{t=1}^{t=n} \frac{B_{t}}{(1+r)^{t}} / \sum_{t=1}^{t=n} \frac{C_{t}}{(1+r)^{t}}
$$

Where,

$$
\begin{aligned}
& B_{t}=\text { Benefits in each year } \\
& C_{t}=\text { Cost in each year } \\
& n=\text { Number of year } \\
& i=\text { Interest rate (discount rate) }
\end{aligned}
$$

If $\mathrm{B}-\mathrm{CR}>1$, then the total revenue is greater than the total cost, if $B-C R=1$ then the total revenue is equal to the total cost and if $\mathrm{B}-\mathrm{CR}<1$ then the revenue is less than the total cost. It was assumed as 10 percent for the analysis of the present study.

\section{(iv) Sensitivity Analysis (Risk And Uncertainty Treatment)}

In order to assess the effects of adverse changes in the project's Net Present Value of cash flow (cash inflow and outflow) for a given change in one variable (either cost or return) at a time. Although, we know that for making a logistic overview about mango production sensitivity analysis is necessary. For this financial measure, two discrete situations are made in order to find out effect of change (increase or decrease cost and return). In the first situation, the total cost of production of mango has been increased by $10 \%$ and $20 \%$ without changing the total return values and decline in total return by also $10 \% 20 \%$ with no change in total cost has been considered in the second situation in order to existing prices structure of inputs used and quantity produce.

\section{Relative Profitability Analysis}

In order to find out relative profitability of mango with some competing crops (wheat, paddy and vegetables) total cost of production, total return, net return and benefit-cost ratio were computed based on current market price of inputs and output has been taken into account.

Total cost $=\mathrm{TFC}_{\mathrm{ij}}+\mathrm{TVC}_{\mathrm{ij}}$

Total return $+\mathrm{TR}_{\mathrm{ij}}=\mathrm{Y}_{\mathrm{ij}} \mathrm{P}_{\mathrm{ij}}$

Net return $=\mathrm{TR}_{\mathrm{ij}}-\mathrm{TC}_{\mathrm{ij}}$ 
Where,

$$
\begin{aligned}
& \mathrm{TC}_{\mathrm{ij}}=\text { Total cost }(₹ \text { ha. } \\
& \left.\mathrm{TFC}_{\mathrm{ij}}\right) \\
& \mathrm{TVC}_{\mathrm{ij}}=\text { Total fixed cost }\left(₹ \text { ha. } .^{-1}\right) \\
& \mathrm{GR}_{\mathrm{ij}}=\text { Total return }\left(₹ \mathrm{ha} \cdot .^{-1}\right) \\
& \mathrm{P}_{\mathrm{ij}}=\text { Price }\left(₹ \text { ha. } .^{-1}\right) \text { of } \mathrm{j}^{\text {th }} \text { crops received by } \mathrm{i}^{\text {th }} \\
& \text { farmer } \\
& \mathrm{Y}_{\mathrm{ij}}=\text { Quantity }\left(\mathrm{qtl} . \mathrm{ha}^{-1}\right) \text { produced }
\end{aligned}
$$

\section{RESULTS AND DISCUSSION}

Financial Viability of Investments in Mango Orchard In order to determine the effectiveness and desirability of a new investment in mango orcharding, the financial viability of investment assessed by project appraisal technique taking four important parameters such as Pay Back Period (PBP), Net Present Value (NPV), Benefit-Cost Ratio (B-CR) and Internal Rate of Return (IRR). The results are presented in Table 1.

Table 1: Financial viability of investments in mango orchard

\begin{tabular}{llll}
\hline $\begin{array}{l}\text { S1. } \\
\text { No. }\end{array}$ & Particulars & Units & Values \\
\hline 1 & $\begin{array}{l}\text { Present value of discounted cost at } \\
\text { 10\% discount factor }\end{array}$ & 784889.58 \\
2 & $\begin{array}{l}\text { Present value of discounted return } \\
10 \% \text { discount factor }\end{array}$ & ₹/ha & 1385126.93 \\
3 & $\begin{array}{l}\text { Net present value or worth } \\
\text { (NPV/W) 10\% discount factor }\end{array}$ & ₹/ha & 600237.34 \\
4 & $\begin{array}{l}\text { Benefit- Cost Ratio (B-CR) 10\% } \\
\text { discount factor }\end{array}$ & Ratio & 1.76 \\
5 & Internal Rate of Return (IRR) & Per & 19.80 \\
6 & Payback period (P) & cent & \\
\hline
\end{tabular}

\section{Net Present Value (NPV)}

Net Present value of an investment is the difference between the present value of series of cash inflows or benefits (returns) and cash outflows (costs) over the productive or economic life period of the mango orchard. The results of the financial feasibility analysis in Lucknow district indicated that the per hectare NPV at 10 percent discount rate for the entire life period of the mango orchard (55 years) was found to be ₹ 600237.34. The NPV was positive indicating that the investments in mango orchard are financially feasible and economically viable.

\section{Benefit-Cost Ratio}

The benefit-cost ratio has been obtained by dividing the discounted net returns or benefit stream by the initial Investment or cost stream. This criterion indicates the rate of return per rupee invested in mango enterprise. The net present value of costs and returns were obtained by discounting the cost and return streams by the opportunity cost of capital. The benefit-cost ratio obtained in mango was 1.76 at 10 percent discount or interest rate. The formal criterion is to accept a project that the test if the benefit-cost ratio of 1 or greater at the opportunity cost of capital. Thus, if $\mathrm{B}-\mathrm{C}$ ratio $>1$ it implies that mango production is economically profitable. If $\mathrm{B}-\mathrm{C}$ ratio $<1$, it implies non-profitability of the investment and when $B-C$ ratio $=1$, then the investment is break even (Gittinger, 1982). The result of B-C ratios is greater than unity and marginally higher, therefore it considered economically preferred and financially viable.

\section{Internal Rate of Return}

The internal rate of return is a discount rate at which the present values of the net cash flows are just equal to zero and the benefit-cost ratio equal to one, (i.e., $\mathrm{NPW}=0$ and $\mathrm{B}-\mathrm{C}$ ratio=1). It is also known as marginal efficiency of capital (rate of profit expected from an extra unit of capital investment), internal rate of return is generally used to assess the desirability of investments or project. The adjusted IRR is observed to be 19.80 percent which is much higher than the opportunity cost of the capital and indicates the investment by orchardist in mango orcharding was economically feasible and financially viable. The decision criteria are to accept independent projects with the internal rate of return equal to or above the cut-off rate or opportunity cost of capital investment (Gittinger, 1982). This implies that when internal rate of return is greater than the cost of capital, the project is viable when internal rate of return is equal to the cost of capital; the project will be break even. However, when IRR is lesser than the cost of capital, the investment is not financially viable. Here, the result is concluded that in the study area the internal rate of return was observed to be above the current base rate or discount rate. Higher the projects internal rate of return, the more desirable it is to undertake the project. 


\section{Pay Back Period (PBP)}

The payback period refers to the time required for the project to pay for itself. In other words, it is the length of the time period required to get back the investment on establishment cost of the orchard. In the present study, the payback period was about 8.2 years. This clearly indicated that it would take 8.2 years to recover the entire establishment cost of the orchard. The foregoing analysis revealed that NPV was positive, B-C Ratio was greater than one and IRR was higher than the opportunity cost of the capital (10\%). The investments in mango crop could be recovered in about eight years after planting. Thus, the results of this study evidently revealed that investments in mango orchard were highly profitable, economically feasible and financially viable.

\section{Sensitivity Analysis (Risk and Uncertainty Treatment)}

One of the real advantages of careful economic and financial project analysis that is used to test is what happens to the earning capacity of the project if events differ from the prediction made about them in planning. How sensitivity is a project's net present worth at financial prices and economic values, or its financial and economic rate of returns or net benefit-investment ratio (B-I ratio), to increased investment costs and fall in returns. Reworking an analysis to see what happens under these changed circumstances is called sensitivity analysis. It is one means of drawing attention to a central reality of project analysis. Projections are inevitably subject to a high of risk and uncertainty about what will actually happen. In subject to the mango cultivation is sensitive to change two principal (cost and return) areas.

Under the financial analysis, it has been assumed that the value of costs and returns both in physical and monetary terms would remain constant throughout the entire economic lifespan of mango trees, but in grass root level, these values and too unstable or fluctuate overtime resulting an inappropriate decision making. In order to incorporate these changes, two discrete situations have been taken into account. In the first situation, the total cost of production of mango has been increased by 10 and 20 percent without changing the total return values and decline in total return by also 10 and 20 percent with no change in total cost has been considered in the second situation.

In the both situations, net present values were found to be positive, benefit-cost ratios were more than one and internal rate of returns or marginal efficiency of investment is also higher than the cut-off rate or opportunity cost of capital (Table 2). So, mango production appeared to be highly prospective or financially viable in the study area in terms of absolute values of net present worth of cash flow (cash outflow and inflow), benefit-cost ratio, internal rate of return, etc.

Table 2: Sensitivity analysis (risk and uncertainty treatment) of mango production in the study area

S1.

No.

Parameters

Units 10 Percent 20 Percent

Situation-I: Increase in total cost but return hold constant

Present value of

1 discounted cost at $\quad$ ₹/ha $\quad 863378.54 \quad 941867.50$

$10 \%$ df

Present value of

2 discounted return at ₹/ha $1385126.93 \quad 1385126.93$ $10 \% \mathrm{df}$

Net present value or

3 worth (NPV/W) at ₹/ha $521748.38 \quad 443259.42$ $10 \% \mathrm{df}$

Benefit Cost Ratio (B- Ratio $1.60 \quad 1.47$
CR) at $10 \% \mathrm{df}$

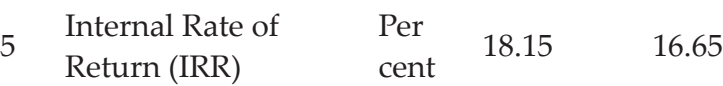

Situation-II: Increase in total return but cost hold constant

\begin{tabular}{|c|c|c|c|}
\hline $\begin{array}{l}\text { Present value of } \\
\text { discounted cost at } \\
10 \% \mathrm{df}\end{array}$ & ₹/ha & 784889.58 & 784889.58 \\
\hline $\begin{array}{l}\text { Present value of } \\
\text { discounted return at } \\
10 \% \mathrm{df}\end{array}$ & ₹/ha & 1246614.23 & 1108101.54 \\
\hline $\begin{array}{l}\text { Net present value or } \\
\text { worth }(\mathrm{NPV} / \mathrm{W}) \text { at } \\
10 \% \mathrm{df}\end{array}$ & ₹/ha & 461724.65 & 323211.96 \\
\hline $\begin{array}{l}\text { Benefit Cost Ratio } \\
\text { (B-CR) at } 10 \% \mathrm{df}\end{array}$ & Ratio & 1.59 & 1.41 \\
\hline $\begin{array}{l}\text { Internal Rate of } \\
\text { Return (IRR) }\end{array}$ & $\begin{array}{l}\text { Per } \\
\text { cent }\end{array}$ & 17.97 & 15.95 \\
\hline
\end{tabular}


Table 3: Relative profitability of mango production with some competing crops

\begin{tabular}{|c|c|c|c|c|c|}
\hline \multicolumn{6}{|l|}{ Mango } \\
\hline Sl. No. & Growing Stages & Total cost ha $^{-1}$ & Total return ha-1 & Net return (TC-TR) ha ${ }^{-1}$ & B-CR \\
\hline 1 & $<7$ & 16784.82 & 0.00 & -16784.82 & -1.00 \\
\hline 2 & $8-17$ & 21623.37 & 68375.26 & 46751.89 & 2.16 \\
\hline 3 & $18-27$ & 26366.21 & 88581.69 & 62215.48 & 2.36 \\
\hline 4 & $28-37$ & 30304.77 & 93116.36 & 62811.59 & 2.07 \\
\hline 5 & $38-47$ & 15913.00 & 44221.97 & 28308.97 & 1.78 \\
\hline \multirow[t]{2}{*}{6} & $<47$ & 45276.10 & 75335.77 & 30059.67 & 0.66 \\
\hline & Overall & 23450.68 & 59481.28 & 36030.60 & 1.54 \\
\hline \multicolumn{6}{|c|}{ Competing crops } \\
\hline S1. No & Competing crops & Total cost of ha- ${ }^{-1}$ & Total return ha-1 & Net return (TC-TR) ha ${ }^{-1}$ & B-CR \\
\hline 1 & Wheat & 31785.53 & 63852.34 & 32066.81 & 1.01 \\
\hline 2 & Paddy & 36659.82 & 71365.83 & 34706.01 & 0.95 \\
\hline 3 & Vegetables & 28538.45 & 64382.74 & 35844.29 & 1.26 \\
\hline 4 & Overall & 32327.93 & 66533.64 & 34205.70 & 1.08 \\
\hline
\end{tabular}

Note: *Figures are the weighted averages of total value.

\section{Relative profitability of mango orchard}

An attempt has been made to estimate the relative profitability of mango production with some dominant competing annual crop (wheat, paddy, vegetables) or crop combinations (wheat + paddy + vegetables) cultivated by farmers under the same agro-climatic condition in terms of annual net returns. For this reason, the net present value estimated earlier over the entire productive or economic life of orchard required to be converted into an average annual net margin or returns in order to make it unbiased comparable with that of annuals at a particular point in time where competing crop or crop combinations were fitted in annual sequence as alternative to mango orcharding by deflating net present value with the annuity factors for the life periods in question at same cutoff rate or discount rate.

Some of the major crop combinations including mango along with their respective average total cost and returns have been presented in table 3. It is observed that although some competing crops performed better in term of benefit-cost ratio, but in terms of net return over the total return of mango cultivation yielded an average annual net return of ₹ 36030.60 ha $^{-1}$ which was noticeably higher than that of other alternative crop or crop combinations. The results implied that the mango cultivation is low input intensive that means fewer requirements of inputs for its production. So, we can say mango production is more financial viable or profitable venture for resource poor farmers.

\section{CONCLUSION}

Due to perennial nature, the cost and return behavior has been estimated @ 10 percent opportunity cost of capital as like investment appraisal for the interest of development of mango entrepreneurs. The per hectare net present value (NPV), for the entire life period (55 years) of the mango orchard has been found to be ₹ 600237.34. Benefit-cost ratio is 1.76. The adjusted IRR is also worked out as 19.80 percent, which is sufficiently higher than the opportunity cost of the capital or the rate of interest demand by the financial institutions. The payback period was about 8.2 years. Thus, the results of this study, evidence reveal that investments in mango orchard are highly profitable, economically feasible and financially viable. To overcome the question of risk and uncertainty in investment over a longer period the usual technique is how sensitive the investment if the cost or return increase/decrease due to economic or other change in market. For this reason, sensitivity analysis based on two basic discrete situations has been worked out. Here also, net present value found to be positive, benefitcost ratio is more than one and the internal rate of returns are also higher than the cut-off rate or opportunity cost of capital. It is also observed that although some competing crop performed better in term of benefit-cost ratio, but in terms of average 
annual net return of ₹ $36030.60 \mathrm{ha}^{-1}$ which was evidently higher than that of alternative crops.

\section{REFERENCES}

DGCIS, 2018-19. Directorate General of Commercial Intelligence and Statistics Kolkata. Ministry of Commerce, Government of India.

Gittinger, J . Price, Prem C. Garg, and Alfred, T. 1982. Current use of Project Analysis Tools in the World Bank and the Inter-American Development Bank. CN-86. Washington, D.C.: Economic Development Institute, World Bank.

Guleria, A., Tiwari, P. and Sharma, R. 2017. Cost of Cultivation and Economic Feasibility of Grafted Harar (Terminalia chebula) In Himachal Pradesh. International Journal of Pure and Applied Bioscience, 5(2): 1005-1011.

Horticultural Statistics at a Glance 2018. Horticulture Statistics Division Department of Agriculture, Cooperation \& Farmers' Welfare Ministry of Agriculture \& Farmers' Welfare Government of India.

Hugar, L.B., Murthy, P.S.S., Umesh, K.B. and Reddy, B.S. 1991. Economic Feasibility of Guava Cultivation under Scientific Management-An Empirical Evidence. Agriculture Situation in India, 46(4): 211-214.

Khandoker, S., Monayem Miah, M.A., Rashid, M.A., Khatun, M. and Kundu, N.D. 2017. Comparative Profitability Analysis of Shifting Land From Field Crops To Mango Cultivation in Selected Areas of Bangladesh. Bangladesh Journal of Agricultural Research, 42(1): 137-158.

Khuda, B., Ishtiaq, H. And Muhammad S.A. 2006. Profitability and Cost in Growing Mango Orchards. Journal of Agriculture and Social Sciences, 2(1): 46-50.

Kumar, S. and Singh, K. 2003. Profitability and Financial Viability of Mango and Kinnow Plantations in Himachal Pradesh. Agricultural Economics Research Review, 16(1): 21-35.

Majumdar, S. and Lahiri, D. 2012. Cost-Benefit and Sensitivity Analysis of Cut Flower Roses and Comparison with other Floricultural Crops. Agricultural Situation in India, pp. 609-624.
Mandal, A.and Subhasis, M. 2016. Financial Feasibility and Constraints of Betelvine Cultivation in Coastal areas of Sundarbans, West Bengal. Journal of Indian Society of Coastal Agricultural Research, 34(1): 148-155.

Mirela, L. and Diana, C. 2009. Project Risk Evaluation Methods - Sensitivity Analysis. Annals of the University of Petrosani, Economics, 9(2): 33-38.

Ramchandra and Neelam Khare 2015. Financial Appraisal of Indian Gooseberry (Emblica officinalis) Cultivation in Pratap Garh District of Uttar Pradesh, India. International Journal of Multidisciplinary Approach and Studies, 2(5): 01-09.

Rymbai, D., Singh, R. Feroze, S.M. and Bardoloi, R. 2012. Benefit-Cost Ratio Analysis of Pineapple Orchard in Meghalaya. Indian Journal of Hill Farming, 25(1): 9-12.

Sahana R.T., Venkatamana, M.N. and Anitha, S. 2017. Economic and Financial Feasibility of Pomegranate Cultivation in Chitradurga District of Karnataka. International Journal of Agricultural Science and Research, 7(1): 127-134.

Saini, L.K., Singh, M. and Kapur, M.L. 2003. Relative Profitability of Intercropping Vegetable Crops in Autumn Planted Sugarcane, 5(1-2): 95-97.

Tripuraneni Jaggaiah. 2015. Returns on Mango Orchard and Economic Feasibility Tests of Mango Orchard in Chittoor District of Andhra Pradesh, Indian Journal of Andhra Pradesh, 5(7).

Singh, S.P. Teerath, R. Anupam, S. Verma, D.K. and Kumar, S. 2019. Relative Economics of Menthol Mint Cultivation with Existing Competitive Crops Combinations in Dudhawa Tinger Reserve Area of Uttar Pradesh. Economic Affairs, 64(4): 725.731.

Surwase, R.V., Kshirsagar, P.J., Talathi, J.M. and Gore, S.T. 2015. Financial feasibility of investment in sapota orchards in Thane district of Maharashtra. International Journal of Commerce and Business Management, 8(1): 47-50. 
